\title{
Influence of Dietary Protein on Embryonic Development and Hatching Traits of Indigenous Guinea Fowl (Numida meleagris) Breeders in Togo
}

\author{
Lamboni Lare $^{1 *}$, Essodina Talaki ${ }^{1,2}$, Koffi Francois-Xavier Dzogbema ${ }^{1}$, Comla Sodjedo ${ }^{2}$, and Yao Lombo ${ }^{3}$ \\ ${ }^{I}$ Centre d'Excellence Régional sur les Sciences Aviaires, Université de Lomé CERSA/UL, O1 B.P. 1515 Lomé, Togo \\ ${ }^{2}$ Ecole Supérieure d'Agronomie, Université de Lomé ESA/UL, 01 B.P. 1515 Lomé, Togo \\ ${ }^{3}$ Institut Togolais de Recherche Agronomique, BP : 1163 Lomé, Togo \\ * Corresponding author's Email: nicody92@gmail.com; ORCID: 0000-0001-7272-3556
}

Received: 02 October 2021

Accepted: 23 November 2021

\begin{abstract}
The diet of breeding indigenous guinea fowl breeders can influence their reproductive performance. Thus, the current study was designed to investigate the effects of different dietary protein intake levels of breeders on embryonic development. A total of 1152 hatching eggs were collected, numbered, weighed, and allocated to 3 groups (control, high-protein [High-P], and low-protein [Low-P]) with 4 replicates of 96 eggs in each dietary treatment group. The eggs were candled on incubation days 9 and 24 . At the end of the hatch, all keets were counted and weighed. Six keets in each group were randomly selected and sacrificed for blood and organ collection. The results showed that the heaviest eggs were for the High-P group and keets at hatch had higher relative hatching muscle weights, compared to the control group. However, the Low-P group had smaller eggs and keets gained lower relative hatching muscle weights compared to the control. Fertility, early mortality rate, and delayed mortality decreased in the High-P group but it increased in the Low-P group, compared to the control. The dietary protein did not influence the incubation time. The maternal diet protein content affected fertility, embryonic development, hatchability, and keet quality. The indigenous guinea fowl breeders need appropriate protein intake to show their potential reproduction performances.
\end{abstract}

Keywords: Guinea fowl, Hatching, Incubation, Nutrition, Protein

\section{INTRODUCTION}

The local guinea fowl or common guinea fowl is the second-highest poultry species after chicken in Togo. It is very important for socio-cultural Togolese events, such as ceremonies, donations, and welcoming of important visitors (Gnassingbe, 1983). The meat of the guinea fowl and its eggs provide immediate satisfaction with protein needs (Sanou, 2005). According to Sanou (2005), the flesh of the guinea fowl is appealing to consumers disgusted by broiler chickens for its "wild" taste. However, the production of guinea fowl has many constraints, such as high keets mortality, the exigency of brooder low fertility, low hatchability, and diet requirement. For the local guinea fowl producers, low fertility, poor hatchability, and poor quality day-old keets are the main impediments.

Poor performance of guinea fowl is linked to the incubation and hatching conditions, age, health, and nutritional status of the parents. Parental nutrition can significantly influence egg and meat quality (Anton et al., 2006). Besides these factors, nutrition can impact the fertility and hatchability of the eggs. Nutritional deficiency in breeder feed can directly result in the abnormal development of the embryo (Bourin et al., 2011). Indeed, feed protein content affects the feed cost of breeder hens (Wu et al., 2007), their laying performance (Wilson, 1997), and their offspring quality and performance (Calini and Sirri, 2007). According to Moran (2007), the feed protein content of the hen's diet has an influence on embryonic development and hatchability. An excessive protein intake in the cocks feed affects their reproductive performance by reducing fertility (Vieira, 2007).

The effect of chickens breeders' diets on their embryonic development and hatchability has been widely investigated by researchers. However, there are few studies on the impact of the breeding diet of local guinea fowl on embryonic development. Moreover, several studies have focused on improving the nutritional quality 
of feed for breeding hens and its optimal effect on offspring (Larbier and Leclercq, 1992). The protein characteristics of feeds are a major nutritional factor in assessing the nutritional value of feeds (Ding et al., 2016) and must be considered when formulating breeder diets (Nideou, 2018). The aim of this study was to assess the impact of dietary protein intake of guinea fowl breeders on their embryonic development.

\section{MATERIALS AND METHODS}

\section{Ethical approval}

Due to the unavailability of the Animal Care Committee at the University of Lomé at the time of this research, the research was conducted under the supervision of the leader of the animal research team following the guidelines of CCOAC (2009).

\section{Experimental design}

A total number of 168 female and 84 male local guinea fowls aged 48 weeks old were allocated into three groups. The fowls were divided into 4 replicates of 14 hens and 7 cocks (Houndonougbo, 2017) according to their dietary treatments. These groups consisted of the control group (control), and the two experimental groups, which included those that received low protein diets (Low$\mathrm{P}$ ), and a group, which received high protein diets (HighP). Diet ingredients and calculated nutritive values are shown in Table 1. A total of 1152 eggs were collected randomly within 10 consecutive days and stored at $15^{\circ} \mathrm{C}$ and $70 \%$ relative humidity prior to incubation. Eggs were numbered, weighed, and allocated to four replicates of 96 eggs per each according to the parent's dietary treatments. The eggs were subjected to the same temperature, humidity, and turning conditions. During the first 24 days, the temperature was $37.7^{\circ} \mathrm{C}$, the humidity was $60 \%$, and the turning occurred automatically every hour at a $90^{\circ}$ angle. On days 9 and 24 of incubation, the eggs were candled to determine fertility and embryonic mortality, respectively. During candling on day 24 , only the eggs containing embryos were weighed and transferred into the hatcher at a temperature of $37.4^{\circ} \mathrm{C}$ with $70 \%$ relative humidity during the remaining days. This weighing allowed us to determine the water loss using the following formula:

$$
\text { Weight loss = P0 - P24 }
$$

Where, P0 is the initial egg weight and P24 refers to weight at 24 days of incubation (Nideou, 2018).

\footnotetext{
Incubation time, hatchability and embryonic mortality, and day-old keets body weight determination

From day 26 of incubation, the keets hatched in each group were counted every three hours until the end of the
}

hatching period. The keets were counted based on dietary treatments and then weighed at the end of the hatch. Unhatched eggs were counted and then broken to identify and count embryonic mortalities. These data were used to determine the incubation time, hatchability, early and late mortality rates, and day-old keets body weight.

Keets weight, carcass weight without the yolk sac, yolk sac weight, and hatching muscle relative weight determination

At the end of the hatch, six keets from each treatment were randomly sampled, weighed, and sacrificed for the blood and the organ collection. The yolk sac and hatching muscle were weighed.

Total proteins, albumin, glucose, triglycerides, and cholesterol levels determination

At post-hatch, blood samples were collected from six local keets from each treatment for the determination of the total protein, albumin, glucose, triglyceride, and cholesterol. The total protein, albumin, triglycerides, and cholesterol concentration of serum was determined using an enzymatic colorimetric method on $25,10,1010$, and 3 $\mu \mathrm{l}$ of serum respectively for the total protein, albumin, glucose triglycerides, and cholesterol. This method is based on the formation of a colored product from which the intensity is proportional to the concentration of the parameter. To validate the test, a standard was assayed and the optical density measurements were made at 546, 630, 500,490 , and $500 \mathrm{~nm}$ for the total protein, albumin, triglycerides, and cholesterol, respectively according to the protocols provided by Cypress Diagnostics from Nijverheidsstraat 82235 Hulshout of Belgium reagent (Cypress Diagnostics, 2020).

\section{Hematology determination}

Blood samples were taken from six keets per treatment in EDTA-impregnated tubes and used to determine the red blood cells (RBC), white blood cells (WBC), Hematocrit (Hte), hemoglobin (Hb), and lymphocytes by $\mathrm{ABX}$ Micros 60, which is a fully automated hematology analyzer (Sysmex Corporation International Company, Japan) according to Nakul et al. (2003).

\section{Statistical analysis}

A commercial scientific 2D graphics and statistics software GraphPad Prism software Inc. (version 5.00.288), a privately held California (USA) corporation (Morgan, 1998) was used to analyze the data. Hatchability and embryo mortality were analyzed by the Chi-square test. The ANOVA test was also used for statistical analysis of the other parameters. The comparison between the different groups after ANOVA was done with the Tukey test. The significant level was set at $\mathrm{p}<0.05$. 
Table 1. Local guinea fowl breeders raised in Togo diet ingredients and macronutrient levels according to treatment and age

\begin{tabular}{|c|c|c|c|c|c|c|c|c|c|}
\hline \multirow[b]{2}{*}{ Ingredients } & \multicolumn{3}{|c|}{ Starter (1-8 weeks) } & \multicolumn{3}{|c|}{ Growth (9-22 weeks) } & \multicolumn{3}{|c|}{ Laying (23-60 weeks) } \\
\hline & Control (\%) & Low-P $(\%)$ & High-P (\%) & Control (\%) & Low-P $(\%)$ & High-P (\%) & Control (\%) & Low-P (\%) & High-P (\%) \\
\hline Maize & 32 & 34 & 21.5 & 53 & 57.5 & 50 & 57 & 61.5 & 53.5 \\
\hline Wheat & 10 & 8 & 7 & 17 & 16.5 & 15 & 10.5 & 10 & 8 \\
\hline Soybeans & 25 & 18 & 27.5 & 15.5 & 11 & 16.5 & 17 & 12 & 19 \\
\hline Dresh & 5 & 3 & 5 & - & - & - & - & - & - \\
\hline Fish & 7 & 10 & 12 & 5 & 6.5 & 7 & 5 & 6 & 6 \\
\hline Millet & 15 & 19 & 21 & - & - & - & - & - & - \\
\hline Flesh concentrated & 5 & 7 & 5 & 5 & 4 & 7 & - & - & - \\
\hline Laying concentrated & - & - & - & - & - & - & 4 & 4 & 7 \\
\hline Shell & 1 & 1 & 1 & 4.5 & 4.5 & 4.5 & 6.5 & 6.5 & 6.5 \\
\hline Total & 100 & 100 & 100 & 100 & 100 & 100 & 100 & 100 & 100 \\
\hline \multicolumn{10}{|l|}{ Analysis } \\
\hline $\mathrm{ME}(\mathrm{kcal} / \mathrm{kg})$ & 2893.7 & 2876 & 2886 & 2757.2 & 2764.53 & 2755.87 & 2802 & 2701 & 2799 \\
\hline Crude protein & 21.34 & 19.69 & 23.06 & 18.04 & 16.57 & 19.55 & 17.13 & 15.67 & 18.62 \\
\hline Calcium & 0.94 & 1.09 & 1.10 & 1.84 & 1.88 & 1.98 & 2.54 & 2.58 & 2.78 \\
\hline Phophorus & 0.78 & 0.87 & 0.82 & 0.73 & 0.72 & 0.83 & 0.70 & 0.70 & 0.84 \\
\hline Methionine & 0.49 & 0.57 & 0.56 & 0.45 & 0.42 & 0.53 & 0.09 & 0.07 & 0.09 \\
\hline Lysine & 1.1 & 1.13 & 1.39 & 0.93 & 0.87 & 1.08 & 0.36 & 0.27 & 0.39 \\
\hline Methionine + cysteine & 0.75 & 0.82 & 0.84 & 0.67 & 0.63 & 0.78 & 0.19 & 0.14 & 0.19 \\
\hline
\end{tabular}

Low-P: Low protein, High-P: High protein, ME: Metabolizable energy. The diet was balanced according to Yildirim (2012). 
Table 2. Effect of protein intake of 48 weeks old local guinea fowl raised in Togo on their egg weight and weight loss during incubation

\begin{tabular}{|c|c|c|c|c|}
\hline \multirow{2}{*}{ Parameters } & \multicolumn{3}{|c|}{ Treatments } & \multirow{2}{*}{ Probability } \\
\hline & Control & High-P & Low-P & \\
\hline Egg weight (g) & $38.46 \pm 0.26^{b}$ & $40.12 \pm 0.36^{\mathrm{a}}$ & $35.38 \pm 0.29^{c}$ & 0.0001 \\
\hline Water loss (g) & $5.54 \pm 0.19^{b}$ & $4.83 \pm 0.08^{c}$ & $6.00 \pm 0.10^{\mathrm{a}}$ & 0.0001 \\
\hline
\end{tabular}

$\overline{\mathrm{a}, \mathrm{b}, \mathrm{c}}$ : Different letters in the same row indicate significant differences $(\mathrm{p}<0.05)$. Low-P: Low protein, High-P: High protein

Table 3. Effect of protein intake of 48 weeks old local guinea fowl raised in Togo on embryonic development and hatchability

\begin{tabular}{lcccc}
\hline \multirow{2}{*}{ Parameters } & \multicolumn{3}{c}{ Treatments } & \multirow{2}{*}{ Probability } \\
\cline { 2 - 4 } & Control & High-P & Low-P & \\
\hline Fertility rate (\%) & $72.49 \pm 1.26^{\mathrm{b}}$ & $61.14 \pm 1.48^{\mathrm{c}}$ & $85.79 \pm 0.48^{\mathrm{a}}$ & 0.0001 \\
Hatch rate (\%) & $84.17 \pm 0.54^{\mathrm{b}}$ & $89.11 \pm 4.00^{\mathrm{a}}$ & $58.92 \pm 3.94^{\mathrm{c}}$ & 0.0004 \\
Early mortality (\%) & $2.44 \pm 1.24^{\mathrm{b}}$ & $0.88 \pm 0.88^{\mathrm{b}}$ & $12.07 \pm 2.05^{\mathrm{a}}$ & 0.0116 \\
Delayed mortality (\%) & $13.38 \pm 0.81^{\mathrm{b}}$ & $10.03 \pm 3.19^{\mathrm{b}}$ & $29.01 \pm 2.01^{\mathrm{a}}$ & 0.0003 \\
Incubation time (hours) & $621.00 \pm 3.24$ & $619.50 \pm 3.35$ & $621.00 \pm 3.24$ & 0.9919 \\
\hline
\end{tabular}

$\overline{\mathrm{a}, \mathrm{b}, \mathrm{c}}$ : Different letters in the same row indicate significant differences $(\mathrm{p}<0.05)$. Low-P: Low protein, High-P: High protein

Table 4. Effect of protein intake of 48 weeks old local guinea fowl breeders raised in Togo on their keets weight at hatch, carcass weight without the yolk sac (YFBM), yolk sac weight, relative hatching muscle weight

\begin{tabular}{|c|c|c|c|c|}
\hline \multirow{2}{*}{ Parameters } & \multicolumn{3}{|c|}{ Treatments } & \multirow{2}{*}{ Probability } \\
\hline & Control & High-P & Low-P & \\
\hline Keets weight at hatch $(\mathrm{g})$ & $22.69 \pm 0.25^{b}$ & $24.38 \pm 0.51^{\mathrm{a}}$ & $20.44 \pm 0.40^{c}$ & 0.0001 \\
\hline Relative weight of hatching muscle (\%) & $0.011 \pm 0.00^{\mathrm{b}}$ & $0.014 \pm 0.00^{\mathrm{a}}$ & $0.010 \pm 0.00^{\mathrm{b}}$ & 0.0001 \\
\hline Yolk sac weight $(\mathrm{g})$ & $1.51 \pm 0.06^{\mathrm{ab}}$ & $1.70 \pm 0.09^{\mathrm{a}}$ & $1.09 \pm 0.09^{\mathrm{b}}$ & 0.0004 \\
\hline $\operatorname{YFBM}(g)$ & $21.00 \pm 0.18^{\mathrm{b}}$ & $22.74 \pm 0.39^{\mathrm{a}}$ & $19.13 \pm 0.28^{c}$ & 0.0001 \\
\hline
\end{tabular}

$\overline{a, b, c}$ : Different letters in the same row indicate significant differences $(\mathrm{p}<0.05)$. Low-P: Low protein, High-P: High protein

Table 5. Effect of protein intake of 48 weeks old local guinea fowl breeders raised in Togo on serum biochemistry of their keets

\begin{tabular}{lcccc}
\hline Parameters & \multicolumn{3}{c}{ Treatments } & \multicolumn{2}{c}{ Probability } \\
\cline { 2 - 4 }$(\mathbf{g} / \mathbf{l})$ & Control & High-P & Low-P & 0.0006 \\
\hline Pt & $22.62 \pm 0.33^{\mathrm{b}}$ & $25.71 \pm 0.68^{\mathrm{a}}$ & $20.54 \pm 0.26^{\mathrm{c}}$ & 0.0001 \\
Alb & $16.22 \pm 0.19^{\mathrm{b}}$ & $17.44 \pm 0.34^{\mathrm{a}}$ & $15.03 \pm 0.12^{\mathrm{c}}$ & 0.1901 \\
Glu & $3.19 \pm 0.18$ & $3.27 \pm 0.17$ & $2.85 \pm 0.06$ & 0.001 \\
Trigl & $0.40 \pm 0.02^{\mathrm{b}}$ & $0.48 \pm 0.03^{\mathrm{a}}$ & $0.30 \pm 0.0^{\mathrm{c}}$ & 0.0001 \\
Chol & $1.57 \pm 0.18$ & $1.65 \pm 0.04$ & $1.48 \pm 0.03$ & 0.1960 \\
\hline
\end{tabular}

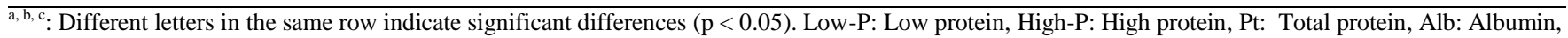
Glu: Glucose, Trigl: Triglycerides, Chol: Cholesterol

Table 6. Effect of protein intake of 48 weeks old local guinea fowl breeders raised in Togo on hematological indices of their keets

\begin{tabular}{|c|c|c|c|c|}
\hline \multirow{2}{*}{$\begin{array}{l}\text { Parameters } \\
(\mathrm{g} / \mathrm{l})\end{array}$} & \multicolumn{3}{|c|}{ Treatments } & \multirow{2}{*}{ Probability } \\
\hline & Control & High-P & Low-P & \\
\hline $\mathrm{RBC}\left(\mathrm{x} 10^{9} / \mathrm{L}\right)$ & $2.62 \pm 0.06^{\mathrm{ab}}$ & $2.67 \pm 0.07^{\mathrm{a}}$ & $2.28 \pm 0.06^{\mathrm{b}}$ & 0.0015 \\
\hline $\mathrm{WBC}\left(\times 10^{12} / \mathrm{L}\right)$ & $78.51 \pm 0.92^{b}$ & $91.95 \pm 0.80^{\mathrm{a}}$ & $74.75 \pm 1.14^{c}$ & 0.0001 \\
\hline $\operatorname{Lym}\left(\times 10^{9} / \mathrm{L}\right)$ & $66.21 \pm 0.75^{\mathrm{a}}$ & $71.46 \pm 3.72^{\mathrm{a}}$ & $53.57 \pm 2.68^{b}$ & 0.0060 \\
\hline Haemo (g/dl) & $18.35 \pm 0.52^{\mathrm{b}}$ & $18.65 \pm 0.27^{\mathrm{a}}$ & $17.47 \pm 0.41^{\mathrm{c}}$ & 0.0001 \\
\hline Hte $(\%)$ & $35.65 \pm 0.36^{\mathrm{a}}$ & $37.54 \pm 0.49^{a}$ & $33.68 \pm 0.65^{b}$ & 0.0004 \\
\hline
\end{tabular}

$\overline{\mathrm{a}, \mathrm{b}, \mathrm{c}}$ : Different superscripts in the same row indicate significant differences $(\mathrm{p}<0.05)$. Low-P: Low protein, High-P: High protein, RBC: Red blood cells, WBC: White blood cells, Lym: Lymphocytes, Hte: Hematocrit, Haemo: Hemoglobin 


\section{RESULTS}

\section{Effect of protein intake of breeder guinea fowls on egg weight and weight loss}

Table 2 shows the weight of the eggs and the weight loss according to the dietary treatment of the parent. In terms of egg weight, keets of the High-P group recorded the highest and the Low-P keets had the lowest eggs weights $(p<0.05)$. For water loss, the results showed that the water loss was significantly higher in the Low-P treatment and lower in the High-P treatment, compared to the control $(\mathrm{p}<0.05)$.

\section{Fertility rate, hatch rate, early embryonic} mortality rate, delayed embryonic mortality rate, and incubation time

The fertility was significantly lower in the High-P group ( $\mathrm{p}<0.05$ ), compared to the control group. On the other hand, it was significantly higher in the Low-P group ( $\mathrm{p}<0.05$ ), compared to the control. The hatchability was significantly higher in the High-P group than that of the control group ( $p<0.05)$. Hatchability was, however, significantly lower in the Low-P group ( $\mathrm{p}<0.05)$, compared with the control. Reducing the protein content of the feed significantly increased the early mortality rate $(\mathrm{p}<0.05)$. However, an increase in protein content did not influence the early mortality rate, compared to the control group. The delayed mortality rate was significantly high in the Low-P treatment ( $p<0.05$ ) but similar to that of the High-P and control treatments. The feed quality did not affect the incubation time because it was similar across all the treatments (Table 3).

Hatching keets weight, carcass weight without the yolk sac weight, yolk sac weight, and relative weight hatching muscle

The weight of the keets at hatch, the yolk free body mass, the weight of the yolk sac, and the relative weight of the hatching muscle are recorded in Table 4. The weights of the keets from the Control, High-P, and Low-P groups are respectively $22.69 \pm 0.25 \mathrm{~g}, 24.38 \pm 0.51 \mathrm{~g}$, and $20.44 \pm$ $0.40 \mathrm{~g}$. The high protein diet significantly increased keets weight at hatch. On the other hand, the reduction in the protein of diet significantly reduced keets weight at hatch $(\mathrm{p}<0.05)$. Keets from the High-P group showed significantly higher relative hatch muscle weight $(\mathrm{p}<$ 0.05), compared to the control group. Nevertheless, the reduction in the protein level did not influence the relative weight of the hatching muscle because they were comparable to the control $(\mathrm{p}>0.05)$. Increasing the protein level of the parents' feed did not affect the yolk sac weight of the keets because their weights were similar to those of the control group ( $p>0.05$ ). However, the keets from the Low-P group showed a significantly low yolk sac weight, compared to the control. Low-P keets exhibited a low carcass weight without the yolk sac compared to the control group ( $\mathrm{p}<0.05)$. On the other hand, the High-P group showed greater carcass weight without the yolk sac $(\mathrm{p}<0.05)$ compared to the control.

\section{Effect of protein variations of breeder guinea fowl on serum biochemistry of keets}

Table 5 shows the serum concentration of the total protein, albumin, glucose, triglycerides, and total cholesterol. The total protein, albumin, and triglycerides concentration of the serum were significantly higher in keets from parents fed by the high protein diets, compared to the control $(\mathrm{p}<0.05)$. However, it was lower in keets whose parents consumed a low protein diet compared to the control $(\mathrm{p}<0.05)$. On the other hand, they were low ( $p$ $<0.05$ ) in the keets whose parents consumed a low protein diet compared to the control group ( $\mathrm{p}<0.05)$. Glucose and cholesterol levels of keets were not affected by maternal $\operatorname{diet}(\mathrm{p}>0.05)$.

Effect of protein variations of breeder guinea fowl on hematological indices of keets

Keets whose parents were fed a low protein ration had low levels of RBC and hematocrit $(\mathrm{p}<0.05)$ while they were similar in keets from the High-P and control parents groups. The Low-P group had the lowest hemoglobin level $(p<0.05)$ and the high protein group had a higher hemoglobin level $(\mathrm{p}<0.05)$, compared to the control. The low protein content of the parent's diet negatively affected the concentration of lymphocytes and WBC in their keets while these concentrations were similar in the High-P and control groups (Table 6).

\section{DISCUSSION}

The nutritional quality of the breeder diet can influence the quality of eggs, embryonic development, hatchability, hematological and biochemical parameters of their offspring. The obtained results of the present study indicated that the eggs of the Low-P group had more moisture loss than those of the control group. According to Jaiswal et al. (2016), this situation could be explained by the high surface-to-volume ratio, that has larger pore areas 
and pore diameters, which thus, become more favorable to gas and heat exchanges in these eggs. Indeed, the eggs from this group showed low weight before incubation. The larger size of the eggs from the High-P group explains their low water loss, compared to the control. In addition, a study conducted by Abanikannda et al. (2011) involving three strains of broiler chickens (Anak-361, Marshall-359, and Ross-282) showed that weight loss was lower in larger eggs than smaller eggs. Similarly, Ulmer-Franco et al. (2010) reported that the percentage of weight loss of incubating eggs decreased with increasing egg size in Cobb 500 broiler breeders. This water loss is due to the porosity of the shell because it significantly influences the loss of water during incubation (Peebles and Brake, 1986). This can be attributed to the fact that there is a mismatch of certain amino acids, such as methionine in the low protein diet, which influences the absorption and retention of calcium. Methionine forms a complex compound with calcium, which slows calcium absorption and increases serum calcium retention. This retention according to Nideou (2018) leads to a greater flow of calcium to the bones and the eggs, resulting in good porosity of the shell and consequently an optimal loss of water by the egg.

The fertility of the High-P group was significantly lower in the present study. This may be due to the excessive supply of nutrients before and during the laying phase period, which increases the deposition of the fat in the reproductive system, thereby blocking the oviduct of the hen to prevent the movement and storage of sperm (Van Emous et al., 2015). Similarly, Larbier and Leclercq (1992) asserted that excessive protein intake in males during the laying phase affected reproductive performance by reducing fertility. In addition, increased protein intake leads to excessive nitrogen excretion with an increased uric acid rejection, which makes the cloacal environment acidic with the consequence of reducing the quality and motility of sperm in storage (De Beer, 2009).

The hatchability of the Low-P group was significantly lower than those of the control and High-P groups. This poor performance is linked to the high rate of early and delayed mortality in this group. These high mortalities could be attributed, in part, to the low egg weights and abundant loss of water from their eggs (Sanfo et al., 2007). On the other hand, a maternal diet low in crude protein may lead to reduced albumin in eggs, which can increase embryonic mortality and decrease the hatching of chicks (Lopez and Leeson, 1994). Indeed, the free amino acids in the yolk originate largely from the diets and induce the growth of the embryo. They are initially used during the early stages of embryonic development. Their partial deficiency has adverse implications on embryonic development (Larbier and Leclercq, 1992). Feeding a diet of $0.21 \%$ methionine instead of $0.36 \%$ reduced the hatching but injection of methionine into the egg eliminates the effects of the deficiency (Larbier and Leclercq, 1992). Furthermore, deficiencies of linoleic acid and linolenic acid partially led to a decrease in egg weight, a reduction in the number of yolk lipids, and an increase in embryonic mortality (Larbier and Leclercq, 1992). Walsh and Brake (1997) demonstrated that the $11 \%$ and $14 \%$ crude protein decreased fertility and hatching than the hen diet of $17 \%$ crude protein. Furthermore, a study by Leeson et al. (1979) showed that nutrient deficiency is the cause of embryonic mortality on the eighth day of incubation. The increase in the level of crude protein in the diet could increase the content of methionine, linoleic acid, linolenic acid, biotin, Vitamins $\mathrm{A}$ and $\mathrm{E}$, and pantothenic acid which explains the high hatchability of the eggs from the High-P group. In addition, keets from the High-P group exhibited greater relative hatching muscle weights than those from the other groups. Indeed, the hatching muscle is an organ that provides the necessary energy for the chick to break the shell by the dorsal than the lateral movement of the head (Nwagu, 1997). The shell of the guinea fowl egg is very hard, the consistency of this muscle, therefore, defines the quality of the hatching. Therefore, the Low-P group with a high embryonic death rate had a low hemoglobin level and the High-P group with a low embryonic mortality rate had a high hemoglobin level. This result corroborates the findings of Harmon (1936) who reported that groups with low mortality had higher hemoglobin levels than those with high mortality.

Feeding the parents with the low protein decreased the concentration of lymphocytes and white blood cells of the keets at hatch. This suggests that these keets have low immunity. This result explains the high mortality rate of the embryos of the Low-P group.

The protein intake of the diet did not influence the incubation time, as it was similar in all treatments. Enting et al. (2007) report that decreasing or increasing protein levels in parental diets had no impact on incubation time. The consumption of the high protein diets increased the weight of the keets at hatching in the current study. This difference could be related to the weight of the eggs, which were heavier in this treatment. The high nutrient reserve content of large eggs may explain the high hatching weight of the keets. A study conducted by Tona et al. (2003) demonstrated that chick weight increases with 
an increase in egg weight because heavier eggs contain more nutrients than smaller eggs. According to Tulletf and Burton (1982), most of the variations in hatching chick weight are associated with the differences in the fresh egg weight and the weight loss during incubation.

The parental diet influenced the serum concentration of the total protein and albumin in keets from parents that consumed high protein feed. In fact, their total serum proteins were significantly higher than those of the control group. This result could be attributed to the high serum concentration of the total protein and albumin of the parents, which strongly influenced the protein profile of the offspring. The early increase in the level of plasma proteins is explained by intense somatic development in keets with a high hatching weight (Nideou, 2018). This increase was also observed in turkeys (Szabo et al., 2005) and Sasso broiler chicks (Nideou, 2018). On the other hand, a low concentration of the total serum proteins was observed in the keets from parents fed a lower content of dietary protein. This result could be attributed to the result of the maternal parents because their parents had low serum total protein concentration. The results of the present study showed that the protein level of the parent feed did not influence the serum cholesterol concentration of the hatched guinea keets. This finding may result from low feed intake in the hepatic synthesis of cholesterol.

The higher serum triglycerides concentration of keets from the parents fed high protein ration is believed to be due to the maternal lipid profile because the parents of the High-P group had a high serum triglycerides concentration. In addition, it was found that these keets had large yolk sacs, which is the unique source of lipid for hatching keets. On the other hand, these types of lipids were low in the serum of keets whose parents consumed a lower content of protein compared to the control group. This could be the consequence of the nutritional deficiency of their parents. According to Zhao et al. (2009), a low concentration of triglycerides would be the consequence of a low lipid profile in the blood reflecting an important transport of amino acids and better lipid metabolism with a strong decrease in fat deposits.

The keets from the Low-P group indicated a low level of red blood cells, hemoglobin, and hematocrit. This means that the protein deficiency in the parents' diets resulted in anemia in their hatching offspring. Indeed, some proteins promote the absorption and binding of iron leading to the optimal synthesis of red blood cells (Johnson-Wimbley and Graham, 2011).

\section{CONCLUSION}

The dietary protein of breeder guinea fowl affected embryonic development and hatchability. The feed with high protein improved the egg weight, keets weight, and hatchability but reduced the rate of fertility. The feed of guinea fowl breeders with low protein content improved fertility but had a negative effect on embryonic development. The protein level of diet had no impact on hematological and biochemical parameters. It is suggested to pursue this study on offspring through to laying.

\section{DECLARATION}

\section{Competing interests}

There is no conflict of interest with the authors in this study.

\section{Authors' contributions}

This study was carried out with gratitude to the contribution of the following authors. Lamboni Lare designed the protocol, collected and analyzed data, drafted the manuscript, and edited the draft. Essodina Talaki validated the protocol, supervised the data collected, and revised critically the manuscript. Koffi François-Xavier Dzogbema and Comla Sodjedo collected data and revised the manuscript. Yao Lombo revised manuscript. All these authors read and approved the final version of the manuscript.

\section{Acknowledgments}

This study was supported by the Regional Center of Excellence on Avian Sciences (CERSA) of University of Lomé in Togo with World Bank grant IDA 5424. The authors wish to express their warm gratitude to World Bank and CERSA for their facility.

\section{Ethical considerations}

This manuscript does not contain plagiarized sentences, has not been published or accepted for publication elsewhere or under editorial review for publication elsewhere. The data are not fabricated or falsified henceforth our Institute's Centre d'Excellence Regional sur les Sciences Aviaires of the University of Lomé representative is fully aware of this submission.

\section{REFERENCES}

\footnotetext{
Abanikannda OTF, Leigh AO, and Giwa AO (2011). Influence of egg weight, breed and age of hens on weight loss of hatching broiler eggs. Archiva Zootechnica, 14(3): 43. Available at: https://www.proquest.com/openview/5eb6f9b8842a68557cccf8e49 $\mathrm{d} 3 \mathrm{c} 32 \mathrm{bc} / 1$ ?pq-origsite $=$ gscholar $\& \mathrm{cbl}=196180$
} 
Anton M, Nau F, and Nys Y (2006). Bioactive egg components and their potential uses. World's Poultry Science Journal, 62(3): 429-438. DOI: https://www.doi.org/10.1017/s004393390600105x.

Bourin M, Gautron J, Berges M, Attucci S, Le Blay G, Labas V, Nys Y, and Rehault-Godbert S (2011). Antimicrobial potential of egg yolk ovoinhibitor, a multidomain Kazal-like inhibitor of chicken egg. Journal of Agricultural and Food Chemistry, 59: 12368-12374. DOI: https://www.doi.org/10.1021/jf203339t.

Calini F, and Sirri F (2007). Breeder nutrition and offspring performance. Brazilian Journal of Poultry Science, 9: 77-83. DOI: https://www.doi.org/10.1590/S1516-635X2007000200001.

Canadian Council on Animal Care (CCOAC) (2009). The care and use of farm animals in research, teaching and testing. Ottawa, ON: CCAC, $12-5$.

Cypress Diagnostics (2020). How To Use A Cypress Diagnostics System - DocPlayer.net. Available at: https://docplayer.net/1452061Contents-29-stains-29-bacteriology-stains-29-hematology-stains29-histopathology-stains-papanicolaou-29-ancillary-products.html.

De Beer M (2009). Current approaches to feeding broiler breeders. World Poultry Science Association (WPSA), 17th European Symposium on Poultry Nutrition, Edinburgh, UK, pp. 23-27. Available at: http://www.wpsa.com/index.php/publications/wpsaproceedings/2009/17th-espn/15-debeer-nutrition2009-pdf

Ding Y, Bu X, Zhang N, Li L, and Zou X (2016). Effects of metabolizable energy and crude protein levels on laying performance, egg quality and serum biochemical indices of Fengda1 layers. Animal Nutrition, 2: 93-98. DOI: https://www.dx.doi.org/10.1016/j.aninu.2016.03.006.

Enting H, Kruip TAM, Verstegen MWA, and van der Aar PJ (2007). The effect of low-density diets on broiler breeder performance during the laying period and on embryonic development of the offspring. Poultry Science, 86 : 850-856. DOI: https://www.doi.org/10.1093/ps/86.5.850.

Gnassingbe CN (1983). Contribution à l'étude de l'élevage de la pintade au Togo. Doctoral dissertation Thèse de Médecine Vétérinaire. Dakar, $\quad$ p. $119 . \quad$ Available at: https://beep.ird.fr/collect/eismv/index/assoc/TD83-19.dir/TD8319.pdf

Jaiswal SK, Raza M, Dilliwar L, and Chaturvedani A (2016). Effect of egg weight on pre-hatch performance in broiler chickens. International Journal of Science, Environment and Technology, 5(6): 4422-4426. Available at: https://www.ijset.net/journal/1466.pdf

Johnson-Wimbley TD, and Graham DY (2011). Diagnosis and management of iron deficiency anemia in the 21st century. Therapeutic Advances in Gastroenterology, 4(3): 177-184. DOI: https://www.doi.org/10.1177/1756283X11398736.

Harmon IW (1936). Hemoglobin regulation in chickens. Poultry Science, 15: DOI: https://www.doi.org/10.3382/ps.0150053.

Houndonougbo VP (2017). Caractérisations phénotypiques des populations de pintades (Numida meleagris) locales élevées au Bénin. Doctoral thesis, University of Liège, Gembloux Agro-Bio Tech, Belgium, p. 130. Available at: https://123dok.net/document/lq5p59ry-caracterisationsphenotypiques-des-populations-de-pintades-numida-meleagrislocales-elevees-au-benin.html.

Larbier M, and Leclercq B (1992). Poultry nutrition and feeding. Paris, France, INRA Editions, p. 355.

Leeson S, Reinhart BS, and Summers JD (1979). Response of white leghorn and Rhode island red breeder hens to dietary deficiencies of synthetic vitamins. 1. Embryo mortality and abnormalities. Canadian Journal of Animal Science, 59: 569-575. DOI: https://www.doi.org/10.4141/cjas79-071.
Lopez G, and Leeson S (1994). Nutrition and broiler breeder performance: A review with emphasis on response to diet protein. Journal of Applied Poultry Research, 3: 303-311. DOI: https://www.doi.org/10.1093/japr/3.3.303.

Moran JET (2007). Nutrition of the developing embryo and hatchling. Poultry Science, 86: 1043-1049. DOI: https://doi.org/10.1093/ps/86.5.1043.

Morgan WT (1998). A review of eight statistics software packages for general use. American Statistician, 52: 70-82. DOI: https://www.doi.org/10.1080/00031305.1998.10480542.

Nakul AD, Sudaka I, Ferrero C, Starck B, and Bayle J (2003). Evaluation of the Sysmex Xe-2100® hematology analyzer in hospital use. Journal Clinical Laboratry Analysis, 17: 113-123. DOI: https://www.doi.org/10.1002/jcla.10083

Nideou D (2018). Effect of feeding of broiler breeders on embryonic development and on the zootechnical performance of chicks. Doctoral thesis, University of Lome, p. 194.

Nwagu BI (1997). Factors affecting fertility and hatchability of guinea fowl eggs in Nigeria. World's Poultry Science Journal, 53(3): 279286. DOI: https://www.doi.org/10.1079/WPS19970022.

Peebles ED, and Brake J (1986). The role of the cuticle in water vapor conductance by the eggshell of broiler breeders. Poultry Science, 65: 1034-1039. DOI: https://www.doi.org/10.3382/ps.0651034.

Sanfo R, Boly HH, Sawadogo L, and Ogle B (2007). Egg weight of the local guinea fowl (Numida meleagris) in the central region of Burkina Faso: Relationship with the variables of artificial incubation and the production of guinea fowl, 25(3): 184-188. Available at: http://www.tropicultura.org/text/v25n3/184.pdf.

Sanou CL (2005). Characteristics of eggs of the local guinea fowl (Numida. meleagris) and their relationship with the parameters of incubation, growth and viability of guinea fowl. Final thesis in Rural Development Engineer, Rural Development Institute, Polytechnic University of Bobo-Dioulasso, Burkina Faso, p. 77.

Szabo A, Mezes M, Horn H, Suto Z, Bazar GY, and Romvari R (2005). Developmental dynamics of some blood biochemical parameters in the growing turkey (Meleagris Gallopavo). Acta Veterinaria Hungarica, $\quad 53: \quad 397-409$ DOI: https://www.doi.org/10.1556/avet.53.2005.4.1.

Tona K, Bamelis F, De Ketelaere B, Bruggeman V, Moraes VMB, Buyse J, Onagbesan O, and Decuypere E (2003). Effects of egg storage time on spread of hatch, chick quality, and chick juvenile growth. Poultry Science, $\quad 82$ : 736-741. DOI: https://www.doi.org/10.1093/ps/82.5.736

Tulletf SG, and Burton FG (1982). Factors affecting the weight and Yter status of the chick at hatch. British Poultry Science, 23: 361-369. DOI: https://www.doi.org/10.1080/00071688208447969.

Ulmer-Franco AM, Fasenko GM, and Christopher EOD (2010). Hatching egg characteristics, chick quality, and broiler performance at 2 breeder flock ages and from 3 egg weights. Poultry Science, 89(12): 2735-2742. DOI: https://www.doi.org/10.3382/ps.2009-00403.

Van Emous RA, Kwakkel RP, Van Krimpen MM, and Hendriks WH (2015). Effects of dietary protein levels during rearing and dietary energy levels during lay on body composition in broiler breeder females. Poultry Science, 94: 1030-1042. DOI: https://www.doi.org/10.3382/ps/pev079.

Vieira SL (2007). Chicken embryo utilization of egg micronutrients. Brazilian Journal of Poultry Science, 9: 1-8. DOI: https://www.doi.org/10.1590/S1516-635X2007000100001

Walsh TJ, and Brake J (1997). The effect of nutrient intake during rearing of broiler breeder females on subsequent fertility. Poultry Science, $\quad 76$ : 297-305. DOI: https://www.doi.org/10.1093/ps/76.2.297.

Wilson HR (1997). Effects of maternal nutrition on hatchability. Poultry Science, 76: 134-143. Available at: 
Lare et al., 2021

https://www.sciencedirect.com/science/article/pii/S0032579119405 269/pdf?md5=f8968aa914c7bf334cdcb37b0a12b3b1\&pid=1-s2.0S0032579119405269-main.pdf

Wu X, Cheng Y, Sui L, Zeng C, Southgate PC, and Yang X (2007). Effect of dietary supplementation of phospholipids and highly unsaturated fatty acids on reproductive performance and offspring quality of Chinese mitten crab, Eriocheir sinensis (H. MilneEdwards), female broodstock. Aquaculture, 273(4): 602-613. DOI: https://www.dx.doi.org/10.1016/j.aquaculture.2007.09.030.

Yildirim A (2012). Nutrition of guinea fowl breeders: A Review. Journal of Animal Science Advances, 2(2): 188-193. Available at:
https://www.semanticscholar.org/paper/Nutrition-of-Guinea-FowlBreeders\%3A-a-Review-

Yi\%CC\%87ldi\%CC\%87ri\%CC\%87m/a3ae1603fd35055a5d2ab68c effeabe1caf6b97b

Zhao JP, Chen JL, Zhao GP, Zheng MQ, Jiang RR, and Wen J (2009). Live performance carcass composition, and blood metabolite responses to dietary nutrient density in two distinct broiler breeds of male chickens. Poultry Science, 88: 2575-2584. DOI: https://www.doi.org/10.3382/ps.2009-00245. 